\title{
Pengaruh Permainan Bola Kasti Terhadap Kemampuan Gerak Motorik Kasar Siswa Kelas V SD Negeri 90 Rejang Lebong
}

\section{The Effect of Bola Kasti Game on Gross Motor Ability of Fifth Grade Students of Public Elementary School 90 Rejang Lebong}

\author{
Fadhlil Hadi $^{1}$, Septian Raibowo ${ }^{2}$, Andika Prabowo ${ }^{3}$ \\ ${ }^{123}$ Pendidikan Jasmani, Universitas Bengkulu, Jl. WR Supratman Kandang Limun, Bengkulu, \\ 3871 , Indonesia
}

\begin{abstract}
Abstrak
Penelitian ini bertujuan untuk mengetahui pengaruh permainan bola kasti terhadap kemampuan gerak motorik kasar. Penelitian ini menggunakan metode eksperimen dengan desain pre-test and post-test one grup. Populasi dalam penelitian ini seluruh kelas V berjumlah 40 siswa, dengan sampel berjumlah 40 siswa, teknik pengambilan sampel menggunakan teknik total sampling. Analisis statistik dalam penelitian ini menggunakan Uji $t$ untuk menguji hipotesis. Hasil penelitian motorik kasar dengan rata-rata pre-test medicine ball yaitu 1.88, rata-rata post-test yaitu 2.07, mengalami peningkatan sebesar $10.11 \%$. Rata-rata pre-test lari 40meter yaitu 7.74, rata-rata post-test yaitu 7.57, mengalami peningkatan sebesar $2.36 \%$. Rata-rata pre-test lari bolak-balik $4 \times 5$ meter yaitu 18.06, rata-rata post-test yaitu 17.68, mengalami peningkatan sebesar $2.11 \%$. Hasil analisis medicine ball $\mathrm{t}$ hitung $>\mathrm{t}$ tabel yaitu $4.66>1.66$. Lari 40meter $\mathrm{t}$ hitung $>\mathrm{t}$ tabel yaitu $1.92>1.66$. Lari bolak-balik $4 \times 5$ meter $t$ hitung $>t$ tabel yaitu $1.82>1.66$. Dengan demikian Ha diterima yaitu terdapat pengaruh permainan bola kasti terhadap kemampuan gerak motorik kasar siswa kelas v Sd Negeri 90 Rejang Lebong.
\end{abstract}

Kata kunci: Bola Kasti, Motorik Kasar, Permainan

\begin{abstract}
This study aims to determine the effected of bola kasti game on gross motor skills. This study used an experimental method with a one-group pre-test and post-test design. The population in this study was 40 students in class $V$, with a sample of 40 students. The sampling technique used was total sampling technique. Statistical analysis in this study used the t-test to test the hypothesis. Gross motor research results with the average pretest medicine ball is 1.88, theaverage post-test is 2.07, an increase of $10.11 \%$. The average pre-test 40 meters run was 7.74, theaverage was post-test 7.57, an increase of $2.36 \%$. The average pre-test running back and forth $4 \times 5$ meters is 18.06, theaverage posttest is 17.68 , an increase of $2.11 \%$. The results of the analysis of medicine ball $t$ count $>t$ table are $4.66>1.66$. Run 40 meters $t$ count $>$ t table that is $1.92>1.66$. Run back and forth $4 \times 5$ meters $t$ count $>$ t table that is $1.82>1.66$. This was accepted, so. there was an influence of bola kasti game on the gross motor skills of fifth grade students of SD Negeri 90 Rejang Lebong
\end{abstract}

Keywords: Bola Kasti, Game, Gross Motor 



\section{PENDAHULUAN}

Aktivitas bermain merupakan kegiatan spontan dan menyegarkan serta mempunyai dampak baik buat anak, dorongan bermain mengaitkan peran dengan sungguh, baik menggunakan alat maupun non alat, tidak berpikir tentang masalah akhir, tidak adanya tekanan dan tanpa menginginkan balasan ataupun penghargaan (Nopiyanto \& Raibowo, 2020) Sehingga motorik bagi anak lebih cepat berkembang karena terbiasa bergerak menggunakan otot-otot besar dan anak akan semakin kuat serta semakin bisa mengkontrol tubuh dengan sendirinya.

Permainan adalah kontes yang berinteraksi antar pemain serta mengikuti ketentuan khusus, bisa dilaksanakan secara kelompok ataupun individu dalam mencapai maksud tertentu. Permainan juga merupakan salah satu wujud kegiatan sosial dalam mengontrol anak pada masanya. Dikarenakan, anak banyak menguras kegiatannya di luar rumah yaitu bermain dengan kawan dibandingkan kegiatan aktif lainnya (Desmita, 2013). Permainan kasti ialah salah satu cabang aktivitas bermain yang sangat terkenal di Indonesia lama sebelum zaman penjajahan Jepang, justru pada zaman Belanda masyarakat sudah dapat mengenal permainan kasti. Pada waktu itu permainan kasti ini sering diperlombakan pada pertandingan antar sekolah, sehingga bisa dikenal serta dapat diterapkan pada tiap sekolah dan juga tidak pada masyarakat (Abe, 2013).

Setiap ayah, ibu atau pengajar menghendaki anak atau muridnya berkembang menjadi orang cerdik, mandiri, inovatif, dan bugar. Buat membuktikan kondisi tersebut, maka penting untuk mengetahui lingkungan bermain anak. Karena masa anak tidaklah sama terhadap anak dewasa. Ruang lingkup gerak anak yaitu bermain, peningkatan penguasaan motorik terkadang terabaikan oleh wali atau guru, sebab tidak mengetahui bahwasanya latihan peningkatan penguasaan motorik anak memang tidak bisa dipisahkan dengan pendidikan. Gerak motorik merupakan gerakan yang menunjukan suatu karakter dari tubuh manusia. Dalam bidang ilmu seperti fisiologi, neurofisiologi, psikologi biasanya menggunakan gerak motorik dalam bidangnya. Diantara perkembangan yang perlu ditumbuhkan anak ialah keterampilan motoriknya (Hasanah, 2016).

Dengan adanya pertumbuhan fisik yang semakin hari mulai matang, dengan itu maka keterampilan motorik setiap anak dipastikan mulai bisa diatur 
supaya menjadi lebih baik. Pada tiap aktivitas geraknya dapat searah lewat minat serta keperluannya. Beranjak kerap anak melakukan kegiatan fisiknya dengan itu dapat menghasilkan efek yang positif dalam perkembangan serta fisik motoriknya supaya memudahkan anak dalam menghadap perencanaan yang terdapat di masa yang hendak tiba (Febrialismanto, 2017).

Saat ini teknologi sudah sangat berkembang pesat sehingga semua aktivitas bisa dilakukan dengan cepat dan mudah, namun dengan kemajuan teknologi ini juga mempunyai dampak lain terutama dalam berbagai aktivitas bermain pada anak (Raibowo et al., 2021). Sebelum zaman teknologi seperti saat ini, olahraga sangat penting menjadi bagian untuk mengisi waktu anak dalam bermain dengan tujuan memperoleh kesenangan. Berbagai aktivitas ini pun sudah mulai terlupakan, dengan ini membuat anak tidak terbiasa bergerak sehingga bisa menghambat pada pertumbuhan dan perkembangan anak.

Terdapat kesenjangan yaitu aktivitas permainan olahraga atau permainan tradisional yang sudah mulai terlupakan dikarenakan anak-anak telah dimanjakan oleh permainan yang mengutamakan teknologi seperti: bermain handphone, laptop, playstation, atau komputer. Terbatasnya kegiatan olahraga di dalam maupun di luar sekolah membuat anak kurang dalam bergerak sehingga anak akan mudah letih karena terlalu lama duduk dibandingkan bergerak seperti lari, lompat atau mengayuh sepeda.

Pendidikan jasmani yang merupakan pendidikan melalui aktivitas jasmani sangat penting untuk anak dalam meningkatkan penguasaan gerak bagi mereka yang masih berkembang, seperti menendang, melempar, menangkap atau melakukan keseimbangan (Prabowo et al., 2020). Berdasarkan uraian diatas membuat peneliti tertarik untuk melakukan penelitian dengan judul "Pengaruh Permainan Bola Kasti Terhadap Kemampuan Gerak Motorik Kasar Siswa Kelas V Sd Negeri 90 Rejang Lebong" karena penelitan ini belum pernah dilaksanakan terutama pada sekolah dasar di Kabupaten Rejang Lebong bertujuan untuk melihat seberapa tingkat efektivitas permainan bola kasti terhadap motorik kasar.

\section{METODE}

Berdasarkan dari permasalahan serta tujuan penelitian yang sudah dibahas sebelumnya, dengan ini metode yang digunakan dalam penelitian "Pengaruh 
Permainan Bola Kasti Terhadap Kemampuan Gerak Motorik Kasar Siswa Kelas V Sd Negeri 90 Rejang Lebong” yaitu dengan metode eksperimen dan menggunakan desain One Group Pre-test and Post-test. Penelitian eksperimen dapat diartikan sebagai cara sebuah penelitian yang digunakan dengan tujuan mencari dampak dari suatu perlakuan terhadap suatu kondisi yang telah dikendalikan (Sugiyono, 2016).

Adapun tempat melakukan penelitian ini yaitu di Sekolah Dasar Negeri 90 Rejang Lebong. Sampel yang digunakan dalam penelitian ini yaitu berjumlah 40 orang kelas lima. Instrumen yang digunakan dalam penelitian ini yaitu test medicine ball, tes lari cepat 40meter dan tes lari kelincahan 4x5 meter.

Teknik untuk mengumpulkan data dalam penelitian yang dilakukan yaitu dengan memberikan percobaan dan latihan, kemudian dampaknya akan kelihatan dari efek latihan itu sendiri. Proses yang dilakukan dalam penelitian ini terdiri dari: pertama melakukan tes awal, kemudian diberi suatu latihan, dan ditutup dengan tes akhir. Teknik analisa hasil data dalam penelitian ini memakai analisa statistik dengan uji normalitas, homogenitas serta hipotesis.

Uji normalitas data bertujuan untuk mengetahui apakah siswa yang telah di uji mempunyai atau mendekati data yang berdistribusi normal atau tidak. Uji normalitas menggunakan rumus Liliefors:

$$
\mathrm{Zi}=\frac{\mathrm{xi}-\mathrm{x}}{\mathrm{S}}
$$

\section{Keterangan:}

$\mathrm{Zi}=$ Angka Baku

$\mathrm{Xi}=$ Angka Pada Data

$\mathrm{X}=$ Nilai Rata-Rata

$\mathrm{S}=$ Simpangan Baku

Jika Xhitung $<$ Xtabel maka data dapat dinyatakan berdistribusi normal dan jika sebaliknya maka data dinyatakan tidak berdistribusi normal (Putra et al., 2019).

Apabila sudah diketahui data berdistribusi normal, maka langkah selanjutnya yaitu melakukan uji homogenitas bertujuan untuk melihat apakah kelompok yang membentuk sampel berasal dari populasi yang homogen. Uji homogenitas yaitu menggunakan uji $\mathrm{F}$ dengan rumus: 


$$
\mathrm{F}=\frac{\text { Varians Terbesar }}{\text { Varians Terkecil }}
$$

Keterangan:

Jika Fhitung $<$ Ftabel artinya kedua data homogen dan jika sebaliknya maka dapat dinyatakan kedua data tidak homogen (Putra et al., 2019).

Jika sudah melakukan uji normalitas dan uji homogenitas, maka untuk langkah selanjutnya yaitu melakukan uji hipotesis. Pengujian hipotesis bertujuan untuk mengetahui ada atau tidak adanya pengaruh terhadap latihan yang telah dilakukan, metode untuk menganalisis data akhir yaitu menggunakan uji t dengan rumus:

$$
\text { to }=\frac{M D}{\text { SEM D }}
$$

Keterangan:

Jika t hitung $>t$ tabel artinya data signifikan.

Jika $\mathrm{t}$ hitung $<\mathrm{t}$ tabel artinya data tidak signifikan.

Tujuan perhitungan persentasi ini untuk mengetahui berapa persen peningkatan setelah diberi suatu latihan.

\section{Persentase peningkatan $=$ Mean Different $\mathrm{x} 100 \%$ \\ Mean Pretest}

Keterangan:

$\mathrm{Md}=$ Rata-rata tes akhir dikurang rata-rata tes awal

$\mathrm{Mp}=$ Rata-rata tes akhir.

(Putra et al., 2019).

\section{HASIL}

Penelitian ini dilaksanakan di Sekolah Dasar Negeri 90 Rejang Lebong. Pengumpulan data awal pretest dilaksanakan pada hari Senin tanggal 1 Maret 2021, sedangkan untuk data akhir posttest dilakukan pada hari Jum'at tanggal 9 April 2021. Pemberian latihan (treatment) dilakukan sebanyak 16 kali pertemuan, dengan 3 kali pertemuan di dalam satu minggu. Hasil analisis statistik deskriptif pre-test medicine ball, diperoleh nilai minimal $=1,5$, nilai maksimal $=2,5$, ratarata $=1,88$, dengan simpangan baku $=0,26$, sedangkan post-test nilai minimal $=$ 
1,6 , nilai maksimal $=2,7$, rata-rata $=2,07$, dengan simpangan baku $=0,25$. Hasil analisis statistik deskriptif pre-test lari 40 meter, diperoleh nilai minimal $=6,7$, nilai maksimal $=9,07$, rata-rata $=7,74$, dengan simpangan baku $=0,59$, sedangkan post-test nilai minimal $=6,49$, nilai maksimal $=8,89$, rata-rata $=7,57$, dengan simpangan baku $=0,58$. Hasil analisis statistik deskriptif pre-test lari bolak-balik 4x5 meter, diperoleh nilai minimal $=15,2$, nilai maksimal $=21,34$, rata-rata $=18,06$, dengan simpangan baku $=1,35$, sedangkan post-test nilai minimal $=15,07$, nilai maksimal $=20,93$, rata-rata $=17,68$, dengan simpangan baku $=1,27$.

\section{Uji Prasyarat Analisis}

Sebelum dilakukan pengujian hipotesis, maka terlebih dahulu perlu dilakukannya uji prasyarat yaitu melalui uji normalitas dan uji homogenitas. Pengujian data yang dilakukan mempunyai hubungan dengan hasil penelitian dan bertujuan untuk membantu analisis sehingga dapat menjadi lebih baik.

\section{Uji Normalitas}

Tabel 1. Rangkuman Uji Normalitas Medicine Ball

\begin{tabular}{ccccc}
\hline Variabel & & Lo & Ltab & Distribusi \\
\hline Pre-test & 0 & 0,13 & 0,14 & Normal \\
Post-test & 0 & 0,11 & 0,14 & Normal \\
\hline
\end{tabular}

Tabel 2. Rangkuman Uji Normalitas Lari 40 Meter

\begin{tabular}{ccccc}
\hline Variabel & Lo & Ltab & Distribusi \\
\hline Pre-test & 0 & 0,065 & 0,14 & Normal \\
Post-test & 0 & 0,066 & 0,14 & Normal \\
\hline
\end{tabular}

Tabel 3. Rangkuman Uji Normalitas Lari Bolak-balik 4x5 Meter

\begin{tabular}{ccccc}
\hline Variabel & N & Lo & Ltab & Distribusi \\
\hline Pre-test & 40 & 0,12 & 0,14 & Normal \\
Post-test & 40 & 0,11 & 0,14 & Normal \\
\hline
\end{tabular}




\section{Uji Homogenitas}

Pada pengujian homogenitas, sampel dapat dikatakan mempunyai varian data yang homogen apabila $F_{\text {hitung }}<\mathrm{F}_{\text {tabel }}$ pada taraf signifikan 0,05 .

Tabel 4. Rangkuman Uji Homogenitas Medicine Ball

\begin{tabular}{cccc}
\hline $\mathbf{N}$ & Fhitung & Ftabel & Kesimpulan \\
40 & 1,05 & 1,70 & Homogen \\
\hline
\end{tabular}

Tabel 5. Rangkuman Uji Homogenitas Lari 40 Meter

\begin{tabular}{cccc}
\hline $\mathbf{N}$ & Fhitung & Ftabel & Kesimpulan \\
40 & 1,03 & 1,70 & Homogen \\
\hline
\end{tabular}

Tabel 6. Rangkuman Uji Homogenitas Lari Bolak-balik 4x5 Meter

\begin{tabular}{cccc}
\hline $\mathbf{N}$ & Fhitung & Ftabel & Kesimpulan \\
40 & 1,13 & 1,70 & Homogen \\
\hline
\end{tabular}

\section{Uji Hipotesis}

Pada pengujian hipotesis menggunakan rumus (uji paired t-test) maka didapatkan hasil akhir analisis yaitu sebagai berikut:

Tabel 7. Rangkuman Hasil (Uji t) Medicine Ball

\begin{tabular}{cccc}
\hline Dk=n1+n2-2 & Thitung & Ttabel $\boldsymbol{\alpha}=\mathbf{0 , 0 5}$ & Kesimpulan \\
78 & 4,66 & 1,66 & Signifikan \\
\hline
\end{tabular}

Dari penghitungan hasil analisis menggunakan uji t, maka dapat dinyatakan terdapat pengaruh dari permainan bola kasti $(\mathrm{x})$ terhadap kemampuan gerak motorik kasar (y) siswa kelas v Sd Negeri 90 Rejang Lebong yang berjumlah 40 siswa. Berdasarkan hasil analisis uji t, maka diperoleh $\mathbf{t}_{\mathbf{h}}=\mathbf{4 , 6 6}>$ tabel $=1,66$ pada taraf signifikasi $\alpha=0,05$ dan besarnya peningkatan permainan bola kasti tersebut dapat dilihat dari kenaikan presentase 10,11\%.

Tabel 8. Rangkuman Hasil (Uji t) Lari 40 Meter

\begin{tabular}{cccc}
\hline Dk=n1+n2-2 & Thitung & Ttabel $\boldsymbol{\alpha}=\mathbf{0 , 0 5}$ & Kesimpulan \\
78 & 1,92 & 1,66 & Signifikan \\
\hline
\end{tabular}


Dari penghitungan hasil analisis menggunakan uji t, maka dapat dinyatakan terdapat pengaruh dari permainan bola kasti $(\mathrm{x})$ terhadap kemampuan gerak motorik kasar (y) siswa kelas v Sd Negeri 90 Rejang Lebong yang berjumlah 40 siswa. Berdasarkan hasil analisis uji t, maka diperoleh $\mathbf{t}_{\mathbf{h}}=\mathbf{1 , 9 2}>$ tabel $=1,66$ pada taraf signifikasi $\alpha=0,05$ dan besarnya peningkatan permainan bola kasti tersebut dapat dilihat dari kenaikan presentase 2,36 \%.

Tabel 9. Rangkuman Hasil (Uji t) Lari Bolak-balik 4x5 Meter

\begin{tabular}{cccc}
\hline $\mathbf{D k}=\mathbf{n} 1+\mathbf{n} 2-\mathbf{2}$ & Thitung & Ttabel $\boldsymbol{\alpha}=\mathbf{0 , 0 5}$ & Kesimpulan \\
78 & 1,82 & 1,66 & Signifikan \\
\hline
\end{tabular}

Dari penghitungan hasil analisis menggunakan uji t, maka dapat dinyatakan terdapat pengaruh dari permainan bola kasti $(\mathrm{x})$ terhadap kemampuan gerak motorik kasar (y) siswa kelas v Sd Negeri 90 Rejang Lebong yang berjumlah 40 siswa. Berdasarkan hasil analisis uji t, maka diperoleh $\mathbf{t}_{\mathbf{h}}=\mathbf{1 , 8 2}>$ tabel $=1,66$ pada taraf signifikasi $\alpha=0,05$ dan besarnya peningkatan permainan bola kasti tersebut dapat dilihat dari kenaikan presentase 2,11\%.

\section{PEMBAHASAN}

Berdasarkan hasil dari uji analisis data, maka dapat menunjukkan bahwa hipotesis yang diajukan diterima. Hasil tersebut menunjukkan bahwa permainan bola kasti dapat memberikan pengaruh terhadap kemampuan gerak motorik kasar, adanya pengaruh tersebut didukung oleh data penelitian. Hal tersebut sesuai dengan unsur dari permainan bola kasti yang banyak melibatkan sebagian atau seluruh otot besar dalam aktivitasnya dengan kecepatan, kelincahan, power dan lainnya, sehingga mampu meningkatkan kemampuan gerak motorik kasar dengan efisien (Dwipa, 2015). Kecepatan merupakan kemampuan untuk melakukan gerakan atau berpindah tempat dalam waktu singkat (Chania et al, 2021). Sedangkan power merupakan gabungan antara kekuatan dan kecepatan yang dibutuhkan dalam setiap aktivitas gerak manusia (Sihombing, 2019). Diantaranya gerakan berlari sambil bermain maka anak dapat lebih baik dan terstimulus dari yang tadinya masih mengalami kesulitan dan belum cepat hingga anak mampu 
untuk berlari secara terarah, gerakan melempar bola pada anak dapat mengenai sasaran dengan tepat dan mempunyai power dalam melempar, serta gerakan menghindari bola lemparan lawan dari yang belum dapat menghindar sehingga dapat menghindar dari lemparan bola lawan dengan kelincahan tubuhnya (Nisa \& Marbun, 2017). Motorik kasar ialah aktivitas jasmani dengan memerlukan otot besar sebagian atau seluruh dalam kegiatannya, motorik kasar meliputi gerakan lokomotor, non lokomotor, serta manipulatif, aktivitas ini juga merupakan gerakan jasmani melalui pengendalian kegiatan otot yang terkoordinasi, misalnya: lari, jalan, dorong, narik, tegak, berdiri menggunakan kaki satu, memanjat, merangkak dan melompat (Sujarwo \& Widi, 2015). Kemampuan motorik kasar ialah suatu aktivitas jasmani yang diakibatkan dengan komponen dari unsur motorik itu sendiri, agar memudahkan untuk melaksanakan keterampilan dalam aktivitas gerak (Komaini, 2018).

Adanya pengaruh tersebut terbukti dengan hasil penelitian dimana tes akhir (post-test) kemampuan gerak motorik kasar menggunakan instrumen medicine ball, lari 40 meter, dan lari bolak-balik 4x5 meter meningkat dari tes awal (pre-test) setelah diberikannya perlakuan berupa permainan bola kasti. Peningkatan motorik tersebut mempunyai kaitan dengan medicine ball yang aktivitasnya melibatkan otot lengan dan bahu sehingga berdampak terhadap power lengan dan bahu, lari 40meter melibatkan kecepatan dalam aktivitasnya sehingga dapat meningkatkan kecepatan dan lari bolak-balik 4x5 meter melibatkan unsur keseimbangan dalam aktivitasnya. Kasti merupakan aktivitas olahraga yang termasuk kategori permainan bola kecil mempunyai dua regu tim yaitu pemukul dan penjaga. Menguasai teknik-teknik dasar dalam permainan ini sangat diperlukan supaya bisa mengaplikasikan permainan lebih baik. Unsur dari permainan ini yaitu: gerakan lari, lempar, menangkap, dan memukul (Hermawan, 2020). Permainan Kasti diketahui banyak mempunyai keuntungan, sampai sekarang ini perlu agar tetap dikembangkan kehadirannya terutama di kawasan masyarakat. Aktivitas ini membawa besar keuntungannya, beberapa manfaatnya yaitu: tidak membutuhkan dana besar dalam bermain dan dapat membentuk daya cipta anak serta lebih mendekatkan anak dengan dunia lingkungan, menumbuhkan keaktifan masyarakat dan sikap emosi anak, meningkatkan keterampilan motorik 
anak serta sebagai media pembelajaran, berguna buat kebugaran tubuh anak dan meningkatkan keterampilan mental anak, menciptakan suasana keceriaan serta kegembiraan dan bisa digunakan oleh semua orang (Anggraini et al, 2018). Sehingga dapat disimpulkan permainan bola kasti berpengaruh terhadap kemampuan gerak motorik kasar siswa kelas V SD Negeri 90 Rejang Lebong. Dikarenakan permainan bola kasti yang banyak melibatkan otot besar dalam aktivitasnya dengan kecepatan, kelincahan, power dan lainnya.

\section{KESIMPULAN}

Berdasarkan dari hasil analisis data serta pembahasan uji hipotesis yang dilakukan menggunakan uji paired t-test. Hasil analisis medicine ball, lari 40meter dan lari bolak-balik terdapat peningkatan. Sehingga dengan demikian dapat disimpulkan $\mathrm{Ha}$ diterima yaitu terdapat pengaruh permainan bola kasti terhadap kemampuan gerak motorik kasar siswa kelas V SD Negeri 90 Rejang Lebong. Unsur dari permainan bola kasti banyak melibatkan otot besar terutama pada power lengan dan bahu, kecepatan lari dan kelincahan tubuh saat melakukan aktivitasnya sehingga dapat meningkatkan keterampilan gerak motorik kasar.

\section{REFERENSI}

Abe, G. (2013). Meningkatkan Keterampilan Melempar dalam Bermain Kasti Melalui Penerapan Bola Modifikasi pada Siswa Kelas V SDN Banyusari. Journal Tadulako Physical Education, 1(5), 1-10.

Anggraini, M. A., Karyanto, Y., \& A.S, W. K. (2018). Pengaruh Permainan Tradisional Lompat Tali terhadap Perkembangan Motorik Kasar Anak Usia 5-6 Tahun. Journal of Early Childhood Care and Education, 1(1), 18. https://doi.org/10.26555/jecce.v1i1.60

Desmita. (2013). Psikologi Perkembangan. (Bandung: PT. Remaja Rosdakarya, 2013).

Dwipa, A. A. (2015). Pengaruh Permainan Tradisional Terhadap Peningkatan Kemampuan Gerak Motorik Kasar Pada Siswa Putra Sekolah Dasar.

Febrialismanto. (2017). Analisis motorik kasar anak usia 5-6 tahun di taman kanak - kanak kecamatan bangkinang kabupaten kampar. Jurnal PGPAUD FKIP Universitas Riau. (Diakses Pada 08 Agutus 2019).

Hasanah, U. (2016). Pengembangan Kemampuan Fisik Motorik Melalui Permainan Tradisional Bagi Anak Usia Dini. Jurnal Pendidikan Anak, 5(1), 717-733. https://doi.org/10.21831/jpa.v5i1.12368

Hermawan, A. H. (2020). Karonball: Modifikasi Permainan Softball untuk Anak usia Kanak-kanak. UNY Press Jl. Gejayan, Gg. Alamanda, Komplek Fakultas Teknik UNY Kampus UNY Karangmalang Yogyakarta 55281.

Komaini, A. (2018). Kemampuan Motorik Anak Usia Dini. PT RajaGrafindo 
Persada, Depok.

Nisa, K., \& Marbun, S. (2017). Pengaruh Permainan Modifikasi Bola Kasti terhadap Perkembangan Motorik Kasar Anak Usia 5-6 Tahun di TK ArRahman T.A 2016-2017. TK Ar-Rahman T.A, 3(1), 43-55.

Nopiyanto, Y. E., \& Raibowo, S. (2020). Pelatihan Olahraga Futsal sebagai Sarana Mengurangi Aktivitas Game Online pada Anak-Anak di Kelurahan Mangunharjo. JURPIKAT (Jurnal Pengabdian Kepada Masyarakat) Politeknik Kebumen, 1(2), 114-124. https://doi.org//10.37339/jurpikat.v1i2.264

Prabowo, A., Waluyo, Marsiyem, \& Ihsan, N. (2020). The Relation of Togok Flexibility and Limb Muscle Power to Perform Power Jump Heading on Football Extracurricular of SMK Negeri 2 Muara Enim Students. Proceedings of the 1st Progress in Social Sciences, Humanities and Education Research Symposium (PSSHERS 2019), 464, 960-962. https://doi.org/10.2991/assehr.k.200824.213

Putra, E. P., Syafrial, S., Sufino, S., \& Defliyanto, D. (2019). Pengaruh Permainan Tradisional Engklek Terhadap Power Otot Tungkai Siswi Di Smp Negeri 10 Kota Bengkulu Tahun 2017/2018. Kinestetik, 2(2), 138-144. https://doi.org/10.33369/jk.v2i2.6492

Raibowo, S., Nopiyanto, Y. E., Sutisyana, A., \& Prabowo, A. (2021). Workshop Pembuatan Bahan Ajar Kesiapsiagaan Bencana Alam dalam Bentuk Multimedia Interaktif Bagi Guru Pendidikan Jasmani. GERVASI: Jurnal Pengabdian Kepada Masyarakat, 5(2), 218-230. https://doi.org/10.31571/gervasi.v5i2.2180

Sugiyono. (2016). Metode Penelitian Kuantitatif, Kualitatif, dan R\&D. CV Alfabeta.

Sujarwo, \& Widi, C. P. (2015). Kemampuan Motorik Kasar dan Halus Anak Usia 4-6 Tahun. Jurnal Pendidikan Jasmani Indonesia, 11(2), 96-100. 